\title{
Erudite Cultural Mediators and the Making of the Renaissance Polymath: The Case of Giorgio Fondulo and Janello Torriani
}

\author{
CRISTIANO ZANETTI
}

European University Institute, Florence

Janello Torriani, also known by his Spanish name Juanelo Turriano (Cremona ca. 1500-Toledo 1585), was a blacksmith, locksmith, constructor of scientific instruments, famous inventor of mechanical devices, automata-maker, clockmaker to Emperor Charles V, hydraulic engineer, mathematician, star-gazer, bell-designer, surveyor, and author of mathematical treatises to King Philip II of Spain. He was especially famous for his amazing planetary clocks, which he both designed and physically crafted (thanks to the invention of the first known machine-tool to cut gears), and for his hydraulic device of Toledo, the first giant machine in history that elevated water over a slope of ninety metres a distance of three hundred meters. Given this multifaceted professional profile, Torriani has been considered a Renaissance polymath and a genius. This article goes beyond the anachronistic understanding of these two categories, which it deconstructs, by analyzing Torriani's education and the context of the mathematical professions during the sixteenth century.

Janello Torriani, aussi connu sous le nom espagnol de Juanelo Turriano (Crémone c. 1500 - Tolède 1585) fut d'abord au service de l'empereur Charles Quint comme forgeron, serrurier, facteur d'instruments scientifiques, inventeur célèbre pour ses dispositifs mécaniques, constructeur d'automates et horloger; au service du roi Philippe II d'Espagne, il fut ingénieur hydraulique, mathématicien, astronome, concepteur de cloches, arpenteur géomètre et auteur de traités de mathématiques. Il est surtout connu pour ses étonnantes horloges astronomiques qu'il a à la fois conçues et construites (grâce à l'invention des premières machines à couper les engrenages), et pour ses dispositifs hydrauliques de Tolède, dont la toute première machine permettant d'amener de l'eau vers le haut d'une pente sur une distance de 300 mètres. Pour ses multiples compétences professionnelles, Torriani est considéré comme un véritable polymathe et un génie de la Renaissance. Cet article cherche à dépasser une compréhension anachronique de ces deux catégories, qu'il pour déconstruit, en analysant la formation de Torriani et le contexte de la profession de mathématicien au XVI siècle. n dealing with the problem of the so-called "Age of the New," Katherine Park
and Lorraine Daston have written that

The multifaceted "Renaissance man" is to some extent a trick of historical perspective, which creates polymathesis out of what was simply a different classification of knowledge and a different professional division of labor. 
[For this reason], early modern career trajectories can often appear to modern eyes at once dazzlingly diverse and oddly circumscribed. ${ }^{1}$

With this case study, I wish to illustrate how one Renaissance superior craftsman or artist-engineer, with his "Vitruvian education," both theoretical and practical, overcame the epistemic boundaries of his time, de facto embodying a polymathesis quadrivialis. Humanist ideology and the role played by cultural mediators are essential to an understanding of the education of such polymaths.

Janello Torriani was considered already in his lifetime to be an exceptional character, able to excel in fields of knowledge that were not expected to be investigated by someone of his status and profession. The first to talk about this dark horse was the physician Girolamo Cardano (Pavia 1501-Rome 1576), who, in his first edition of De libris propriis (1544), attributed the reconstruction of a complex planetary instrument to Torriani. ${ }^{2}$ Six years later (1550), in the first edition of his bestseller De subtilitate, Cardano added that Torriani, to whom he also attributed several inventions, was "a man of great ingenuity in anything that concerns machines." ${ }^{3}$ In the same year, another famous writer, Torriani's countryman Marco Girolamo Vida (1480-1566), definitively consecrated Torriani's reputation for genius as the clockmaker who devised the first springdriven moveable planetary clock for Emperor Charles V. In a booklet intended to praise Cremona over Pavia, two cities in the duchy of Milan, ${ }^{4}$ Vida lists Torriani among the excellences of his city:

It is more and more repulsive to see him always with his face, hair and beard covered and blackened with plenty of ash and repugnant tar. His hands and gross, enormous fingers are always coated with rust [...] for

1. Lorraine Daston and Katharine Park, eds., The Cambridge History of Science, 3 vols. (Cambridge: Cambridge University Press, 2006), 3:5-6.

2. Girolamo Cardano, De sapientia libri quinque. Ejusdem de consolatione libri tres [...] Ejusdem de libris propriis liber unus (Nuremberg: Apud J. Petreium, 1544), 418-19.

3. "Ianellus Turrianus Cremonensis, vir magni ingenii in omnibus quae ad machinas pertinet, opere ipso expressit"; Cardano, De subtilitate libri XXI (Nuremberg: Apud Ioh. Petreium, 1550), 7. Here and henceforth, unless otherwise indicated, all translations are my own.

4. The speech, which was supposed to be read in front of the Senate of Milan (there was a harsh dispute for precedence between Cremona and Pavia within the hierarchy of the duchy), was never given, although the text was circulated. 
he moulds everything he makes at the anvil with his own hands, being a born worker at the forge. However, lest anyone should imagine that some excellent master in mathematics has prepared for him the calculations of the orbits, of the motions or of the stars and has solved it all for him before because he understands nothing about these things, but is only skilled in craftsmanship, let him know that he invents them all and fabricates them by himself with no help of any kind, using his own talent, his own research, his own fancy, as they say. He is both inventor and executor at once [...] often, with assurance and wisdom he contradicts recognized authorities on Astrology, authors of books on it. On not a few occasions he convinces them with incontrovertible arguments, obliging them to admit their errors and blunders. ${ }^{5}$

It can be seen that the image of a craftsman ignorant of Latin yet able to correct university-trained people was a well-established literary topos in the duchy of Milan; indeed, some decades earlier, Leonardo da Vinci had used similar arguments, stating that "experience" was his source, and not books. ${ }^{6}$ The idea of experience as a source of knowledge was not new, ${ }^{7}$ but Torriani's

5. Marco Girolamo Vida, Cremonensium orationes III adversus papienses in controversia principatus (Cremona: Giovanni Muzio e Bernardino Locheta, 1550). Here, I use the translation by Charles David Ley, based on José A. García-Diego's Spanish translation; see José A. García-Diego, Juanelo Turriano, Charles V's Clockmaker: The Man and His Legend (Wadhurst, Sussex: Antiquarian Horological Society / Madrid: Editorial Castalia, 1986), 54.

6. "[T]hey will say that since I do not have literary learning I cannot possibly express the things I wish to treat, but they do not grasp that my concerns are better handled through experience rather than bookishness. Though I may not know, like them, how to cite from the authors, I will cite something far more worthy, quoting experience, mistress of their masters"; see Leonardo da Vinci, Leonardo on Painting: An Anthology of Writings, ed. Martin Kemp (New Haven: Yale University Press, 1989), 9.

7. The idea of the profitable role of empirical experience belongs to the Aristotelian tradition, and despite the problems concerning its ambiguous relation to mathematics, it was well accepted in medieval Christendom. See, for instance, the English Franciscan Roger Bacon's Opus Majus (1214-94), where one can read the famous sentence "Sine experientia sufficienter nihil sciri potest": Roger Bacon, Opus Majus of Roger Bacon, vol. 1, ed. John Henry Bridges (New York: Cambridge University Press, 2010), 167. The use of machines as a tool to gain experience through practice seems to take place during the Renaissance, thanks to the diffusion of the works by Archimedes and Vitruvius and the Quaestiones Mechaincae attributed to Aristotle. For instance, Duke Ottavio Farnese's court physician Giuseppe Ceredi (1520-70), in his book on the Archimedean screw, states that both Aristotle and Galen supported the idea that "No science nor art, whose last aim is placed into practical operation can be perfectly 
story, though similar in the defence of artisans as owners of science, tells us something else: in Vida's text we can detect the Vitruvian ideal of complete knowledge, ${ }^{8}$ which "is the son of practice and theory" ("nascitur ex fabrica et ratiocinatione"). ${ }^{9}$ After all, a planetary clock was the analogical representation of the synchronized movements of the seven erratic planets; besides superior artisanal skills, it also required the most sophisticated scientific astronomical knowledge of the time. There were cases where the artisan crafted the clock, after a mathematician - often a physician-had designed it. In Torriani's case, all contemporary sources emphasize the fact that he himself designed it. Torriani would go on to write mathematical tracts and to tell Ambrosio de Morales, the royal historiographer to King Philip II of Spain, that he had never met anybody with a better command of arithmetic than himself. ${ }^{10}$ And yet Torriani, though singular in his long and complex carrier, was not unique. ${ }^{11}$

mastered, if one who has comprehended the rules does not confirm them with many and different successful experiments" (my translation); see Giuseppe Ceredi, Tre discorsi sopra il modo d'alzar acque da' luoghi bassi. Per adacquar terreni. Per leuar l'acque sorgenti, \& piouute dalle ca[m]pagne, che no possono naturalmente dar loro il decorso. Per mandare l'acqua da bere alle Città, che n'hanno bisogno, \& per altrisimili vsi. Opera non piu stampata (Parma: Appresso Seth Viotti, 1567), 7.

8. Janello Torriani came from the same region as Cesare Cesariano (1475-1543), who was the first author of a vernacular printed and illustrated version of Vitruvius's De architectura (1521), considered one of the most seminal classical works of the Renaissance. Especially in the first book, Vitruvius illustrates his epistemic concept of knowledge proper to his idea of an architect, the model for any Renaissance artisan who aspired to be respected. See Cesare Cesariano and Vitruvius Pollio, Di Lucio Vitruvio Pollione De architectura libri dece traducti de Latino in vulgare affigurati: commentati \& con mirando ordine insigniti (Como: P[er] Magistro Gotardo da Po[n]te, 1521), cx.

9. Vitruvius Pollio, The Ten Books on Architecture, trans. Morris Hicky Morgan, ed. Herbert Langford Warren and Morris H. Morgan (Cambridge, MA: Harvard University Press, 1919), ch. 1.

10. Ambrosio de Morales, Las antiguedades de las ciudades de España que van nombradas en la Coronica, con la aueriguacion de sus sitios, y nōbres antiguos (Alcala de Henares: en casa de Iuan Iñiguez de Lequeríca, 1575), fols. 91-94.

11. For instance, in 1547 the mathematician, writer, and calligrapher Johann Neudörffer the Elder of Nuremberg wrote that a locksmith "with no letters," a certain Hanns Bülmann (or Jacob Büllmann or Püllmann), was able to build a mechanical Theoretica planetarum, a structure similar to Torriani's first great creation. See Jeffrey Chipps Smith, "Nuremberg and the Topographies of Expectation," Journal of the Northern Renaissance 1 (2009), online journal, http://www.northernrenaissance.org/ nuremberg-and-the-topographies-of-expectation/; Johann Neudörffer, Des Johann Neudörfer, Schreibund Rechenmeisters zu Nürnberg, Nachrichten von Künstlern und Werkleuten daselbst aus dem Jahre 1547, ed. Andreas Gulden and Georg Wolfgang Karl Lochner (Osnabrück: Zeller, 1970), 65-66; Gerhard 
In the same year as Vida's pamphlet, we find an interesting parallel for the trope of a craftsman competing with a university professor, in Giorgio Vasari's account of Filippo Brunelleschi's friendship with physician, professor, and mathematician Paolo dal Pozzo Toscanelli:

Having listened to him discussing the mathematical sciences, Filippo struck up such a friendship with Paolo that he learned geometry from him. And although Filippo was not a learned man [did not read Latin], he was able to argue everything so well from his own practice and experience that he confounded Paolo on many occasions. ${ }^{12}$

It seems that the narrative of a contrast between two different systems of knowledge, one learned in the university and the other in the workshop, did not apply to the space of the workshop of the "superior craftsman."13 Both in the urban workshop and at court (but no longer in the monasteries, as had generally been the case in previous centuries), those scholars who were fascinated with the crafts ennobled the figure of the modern artisan on the basis of models taken from Antiquity: this is why in the emperor's official documents acknowledging Torriani's accomplishment, the craftsman was not called a "clockmaker" but an "architect of clocks." In the following years, Torriani came to be described as a new Archimedes and a new Daedalus, as did many other successful craftsmen of his time. ${ }^{14}$ With their libraries and academies, courts played a central role

Dohrn-van Rossum, History of the Hour: Clocks and Modern Temporal Orders (Chicago: University of Chicago Press, 1996), 185.

12. Giorgio Vasari, The Lives of the Artists, ed. Julia Conaway Bondanella and Peter E. Bondanella (Oxford: Oxford University Press, 1991), 114; Giorgio Vasari, Le vite de' piú eccellenti architetti, pittori, et scultori italiani: da Cimabue insino a' tempi nostri: nell edizione per i tipi di Lorenzo Torrentino, Firenze, 1550, ed. Luciano Bellosi and Aldo Rossi (Turin: G. Einaudi, 1986), 296.

13. In the early 1940s, Edgar Zilsel, the social historian of science, identified a certain typology of the Renaissance artisan, which he defined with the categories of "artist-engineer" or "superior craftsman," one of the precursors of the Scientific Revolution; see Edgar Zilsel and Joseph Needham, The Social Origins of Modern Science, ed. Diederick Raven, Wolfgang Krohn, and R. S. Cohen (Dordrecht; Boston: Kluwer Academic Publishers, 2000), 4-5.

14. In Brussels and in Spain, Torriani ran a court workshop with the aid of several servants and with both practical and theoretical duties. He was given physical spaces in which he could set up his workshop, offices, and forge, and it was in these spaces that he built clocks, instruments, and the components for the Toledo Device. On a more intellectual level, Torriani and his workers were required to write technical treatises 
in the promotion of applied mathematics. ${ }^{15}$ Though coming to full maturity only in the sixteenth century, this process had a long history dating back to the European communal administrations of the twelfth and thirteenth centuries, which had moulded urban space and the countryside, creating offices for functions connected with mechanics. Engineers, architects, surveyors, and public clock-keepers had a position before specific curricula were created, making their practitioners de facto polymaths. The first attempt to organize a proper guild for engineers and surveyors was made in Milan in $1505 ;{ }^{16}$ the first guild of clockmakers appeared in Paris in $1544 .{ }^{17}$

In addition to the works of Archimedes, it appears that another classical author played a central role in the process of the ennoblement of applied

for the Crown, partake in astronomical observations with academicians, survey other people's work, and draft projects. Enthusiastic literati, such as Ambrosio de Morales and Esteban de Garibay, powerful officials like the architect Juan de Herrera, and nobles of the court visited Torriani's work space. When Torriani died, the king asked for six chests full of papers, books, and iron instruments to be brought to El Escorial, although the contents have now been scattered. On March 1575, Torriani was ordered to finish within a year the book he had already begun on the functioning and maintenance of the two clocks he had created for the emperor. In 1577, Juan López de Velasco, the royal cosmographer, organized a systematic scientific observation of an eclipse of the moon: the phenomenon was observed by Juan López de Velasco and Andrés García de Céspedes of Madrid, Torriani, and a certain Dr. Sobrino of Toledo, Rodrigo Zamorano of Seville, and Jaime Juan of Mexico. In the late 1570s, the king ordered Torriani to write a tract for the reform of the calendar. See Luis Cervera Vera, Documentos biográficos de Juanelo Turriano (Madrid: Fundación Juanelo Turriano, 1996), docs. 24, 50, 125, 126 and 132; Carlos Enrique Esteve Secall, "Aspectos histórico-gráficos de una observación a escala intercontinental: Las Instrucciones del Cosmógrafo Lopez de Velasco," in XVI congreso internacional de ingeniería gráfica (Zaragoza: Ingeograf, Studium generalem civitatis Caesaraugustanae, 2004), online, www.egrafica.unizar.es/.../Comunicacion17110.pdf; and Juanelo Turriano, Breve discurso a su majestad el Rey Católico en torno a la reducción del año y reforma del calendario: con la explicación de los instrumentos inventados para enseñar su uso en la prática, ed. José A García-Diego and José María González Aboin (Madrid: Fundación Juanelo Turriano, 1990).

15. For academies and libraries at the Spanish court see María Isabel Vicente Maroto, "Juan de Herrera: un hombre de ciencia," in Juan de Herrera y su influencia. Actas del simposio, Camargo, 14/17 julio 1992, dir. Miguel Angel Aramburu-Zabala, coord. Javier Gómez Martínez (Santander: Fundación Obra Pía Juan de Herrera / Universidad de Cantabria, 1993), pp. 79-89, 81. For mathematical institutions at the Spanish court see José María López Piñero, ed., Historia de la ciencia y de la técnica en la Corona de Castilla: Siglos XVI y XVII. Historia de la ciencia y de la técnica en la Corona de Castilla, 3 (León: Junta de Castilla y León, Consejería de Educación y Cultura, 2002).

16. See Milan, Biblioteca Trivulziana, MS 225, "Statuti et Regole per l'Ingegneri et Agrimensori del Duc.o di Milano."

17. Dohrn-van Rossum, 390. 
mathematics, namely Aristotle. By the mid-sixteenth century, when Cardano published his De subtilitate, mechanics, as a scientia media set between theory and practice, ${ }^{18}$ was widely considered to be a branch of mathematics. Aristotle's Mechanics, which was perhaps already known in medieval Europe and had certainly been reintroduced into Italy by the Greek scholar and future cardinal Basilios Bessarion (1403-72), first circulated in manuscript form and then in a printed edition by Aldo Manuzio (1497). It was eventually published in Latin and even in vernacular translations in the first half of the sixteenth century. ${ }^{19}$ This work stated that mechanical problems were related to the fields of both mathematics and natural science, thereby putting method (mathematics) in the place of practice (nature). The workshop of the superior craftsman thus presented to the scholar not an alternative but rather a complementary way to read nature, comprised of a joyful interaction between people with a varied education. Giorgio Fondulo, Torriani's mentor and one of the main characters of our story, just like Paolo dal Pozzo Toscanelli, Leon Battista Alberti, or Luca Pacioli before him, was part of a group of university-related humanists who

18. A concept used by Aristotle in his Posterior Analytics (1:41) where he states that there are pure mathematical sciences (arithmetic and geometry) and "mixed," "subaltern," or "middle" ones, such as optics and harmonics. By the end of the sixteenth century there would be an intense academic debate on these issues. However, the concept of scientiae mediae was not a Renaissance rediscovery: Thomas Aquinas, from among the medieval commentators of the Organon, had already discussed this passage of the Posterior Analytics. See Mario Otto Helbing, "La scienza della meccanica nel Cinquecento," in Il Rinascimento italiano e l'Europa, ed. Antonio Clericuzio and Germana Ernst (Costabissara (VI): Angelo Colla Editore, 2008), 573-92. On Regiomontanus's claim of astronomy as a scientia media that was superior even to the pure mathematical sciences, see Darrel H. Rutkin, "L'astrologia da Alberto Magno a Giovanni Pico della Mirandola," in Il Rinascimento italiano e l'Europa, ed. Antonio Clericuzio and Germana Ernst (Costabissara (VI): Angelo Colla Editore, 2008), 47-58, 53. On the meaning of experience and the debate on the scientific status of mixed mathematical sciences in the early modern period, see Peter Dear, “The Meanings of Experience," in The Cambridge History of Science, ed. Lorraine Daston and Katharine Park (Cambridge: Cambridge University Press, 2006), 3:106-31, 119-22. On Thomas Aquinas's commentary on the Posterior Analytics, see Alberto Strumia, Introduzione alla filosofia delle scienze (Bologna: Edizioni Studio domenicano, 1992), 26. See also, Aristotle, Analitici secondi, in Organon, ed. Mario Mignucci (Rome: GLF Editori Laterza, 2007).

19. In the fifteenth and sixteenth centuries this text was deemed to be by Aristotle and was incorporated into the Corpus Aristotelicum. Although no longer attributed to him, modern historians of science agree that it is consistent with the tradition of Aristotle's Lyceum; see Helbing, 573-92; Paul Lawrence Rose and Stillman Drake, “The Pseudo-Aristotelian Questions of Mechanics in Renaissance Culture," Studies in the Renaissance 18 (1971): 65-104. 
enthusiastically interacted with artisans. A similar trend can be detected in other regions of Europe, often accompanied by what appears to be a specific polemic genre against pedantry. ${ }^{20}$ The common background for these artisans and scholars was mathematics.

Once integrated within the court system, Torriani could openly boast the title of first mathematician royal; nobody doubted his claim. The question is, how did "illiterate" (i.e., unable to read Latin) craftsmen such as Torriani acquire the necessary mathematical knowledge found in Latin and Greek university texts that enabled them to design complex and accurate mathematical instruments? Many contemporary accounts sought to explain Torriani's supreme mathematical knowledge as the effect of a natural predisposition. In one sixteenth-century manuscript, a young and poor Torriani is represented as having the gift of divine intellect. ${ }^{21}$ Such a model, where economic poverty

20. For instance, in the cases of the Valencian Luis Vives (1530s) and the French Petrus Ramus (1560s), humanist apologetic discourses of artisanal knowledge, in contrast to university ones, were produced by individuals who had been trained at a university; therefore, such discourses cannot be taken as a rejection of the complete academic system of the time. Paolo Rossi highlighted this trend in the attacks against pedantry by Erasmus and Montaigne. Pamela H. Smith has collected some of the learned claims produced in a northern European university context; for instance, she has noted that the Valencian humanist Luis Vives "remarked in 1531 that scholars should not 'be ashamed to enter into shops and factories, and to ask questions from craftsmen, and to get to know about the details of their work.' When living in the southern Netherlands, Vives also advised his students to imitate the example of the fifteenth-century Louvain scholar Carolus Virulus, who sought out the fathers of his students in order to learn from them about their trades"; Pamela H. Smith, The Body of the Artisan: Art and Experience in the Scientific Revolution (Chicago: University of Chicago Press, 2004), 66-67. In 1538 Vives had also used the figure of Albrecht Dürer in a fictional dialogue between the Nuremberg painter and two scholars, in order to stigmatize the stupidity of learned pedantry versus smart practical knowledge. But Vives, Ramus, and Virulus were scholars too; see Paolo Rossi, I filosofi e le macchine, 1400-1700 (Milan: Feltrinelli, 2007), 27.

21. A certain Camillo Capilupi (1531-1603), a Mantuan gentleman connected to Torriani's patronage network, wrote that "Master Janello Cremonese, born in the county, as a result of his virtue and the force of his genius, while he was attending the herd in the countryside, would contemplate the motion of the stars and the sky [...]; in a very short time, as he was extremely clever in those arts, he had learned so much that he started to craft clocks with his hands, and he proved himself in mathematics, so that in both professions he accomplished wonderful deeds" (my translation); Rome, Biblioteca Nazionale di Roma, MS Vittorio Emanuele 1062, “Quesito elegantísimo di Maestro Janello a Carlo V Imperatore.” I have examined the pages of García-Diego's draft manuscript on Torriani's biography in an effort to find some clues about this document. I would like to thank the Fundación Juanelo Turriano for allowing me access to these papers. 
elevates a natural intellectual richness, was widely popular in the Renaissance, as we can see in Vitruvius's narration of Ctesibius's origins or in Vasari's narrative of Giotto's youth. ${ }^{22}$ For more factual information on Torriani's youth and education we can turn to the only contemporary published account on him, written by Antonio Campi (1524-87), a countryman of Torriani, in 1585, the same year in which the clockmaker died: ${ }^{23}$

Of all the craftsmen our city had, none has given to it more honour than Lionello [sic] Torriano, a man of low origins, but gifted by God with such a sublime ingeniousness that he astonished the world, and everybody reckoned him to be a miracle of Nature because, even though he has always been illiterate, he was able to talk about astrology and about the other mathematical arts so profoundly and on such a [strong] basis, that he seemed to have always attended to nothing but that. He learned astrology before reading, his teacher being Giorgio Fondulo, doctor in medicine, philosopher and excellent mathematician, who, recognizing his supernatural genius, loved Torriani very deeply. ${ }^{24}$

22. This model remained popular in the seventeenth century, when Vincenzo Viviani, in his description of Galileo Galilei's youth, underlined the contrast between his inborn genius, which enabled him when still a child to recreate models of machines that he had had the chance to observe, and the economic difficulties that impeded his education as a result of his father's financial situation: Vincenzo Viviani, "Racconto istorico della vita del Sig. Galileo Galilei nobil fiorentino," in Fasti consolari dell'Accademia fiorentina di Salvino Salvini consolo della medesima e rettore generale dello Studio di Firenze, ed. Salvino Salvini (Florence: nella stamperia di S.A.R., per Gio. Gaetano Tartini, e Santi Franchi, 1717), $397-446$. See also Vitruvius, The Ten Books on Architecture, 325; and Vasari, Le vite, 299-300. Torriani's twentiethcentury biographer García-Diego took Torriani's alleged poverty as a matter of fact, and not as a topos, in Juanelo Turriano, 35, 41.

23. Antonio came from a famous family of painters. He too was a painter, as well as a sculptor, mapmaker, and historiographer. In addition to his vast and much-praised artistic activity, Antonio Campi's most famous work was the Cremona fedelissima città, et nobilissima colonia dei Romani, a historical work published in 1585 and offered to Philip II. For information on his huge library, see Carlo Bonetti, "La libreria dello storico e pittore Antonio Campi," Cremona 4 (1932): 5-11.

24. Antonio Campi, Cremona fedelissima citta et nobilissima colonia de Romani rappresentata in disegno col suo contado: et illustrata d'una breve historia delle cose piu notabili appartenenti ad essa et de $i$ ritratti naturali de duchi et duchesse di Milano e compendio delle lor vite (Cremona: In casa dell'istesso auttore, 1585), fol. $\mathrm{l}^{\mathrm{v}}$. 
Campi is a reliable witness. ${ }^{25} \mathrm{His}$ account of the physician Giorgio Fondulo (1473-1545) tending to a talented but low-class Torriani introduces us to the pedagogical paradigm of humanist ideology and its commitment to encourage those with a precocious predisposition to undertake higher education. ${ }^{26}$

Fondulo had most probably studied at the University of Pavia and certainly taught there. ${ }^{27}$ By 1505 , he was already practising medicine back in Cremona. We know this from the only known surviving text written by Fondulo himself, ${ }^{28}$ in a manuscript that contains the transcript of an epistolary exchange he had had with Paolo Trizio (or da Trezzo), a professor of medicine, astrology, and philosophy at the University of Pavia. ${ }^{29}$ If Torriani had followed the general

25. Cristiano Zanetti, Juanelo Turriano de Cremona a la Corte (Madrid: Fundacíon Juanelo Turriano, 2015), 32-33.

26. On free education for poor children in Renaissance culture, see Vergerio, 102-09, and Paul F. Grendler, Schooling in Renaissance Italy: Literacy and Learning, 1300-1600 (Baltimore: Johns Hopkins University Press, 1989), 3 and 105.

27. Although the date at which Fondulo began his academic career (1497) has been ascertained, the point at which it ended is still unknown. He was registered as professor "ad lecturam Philosophiae moralis, in festis" at the Faculty of Arts of the University of Pavia, and not at Padua as Spanish historiography continues to insist; see Alfonso Corradi, Memorie e documenti per la storia dell'Università di Pavia e degli uomini più illustri che v'insegnarono (Pavia: Bizzoni, 1878), 168. Moral philosophy was a minor lectureship in Italy; in Pavia it was taught in holiday classes by one or two professors (sometimes friars) who were paid a low salary, and was comprised of the study of humanist studies, natural philosophy, and the "Christian Aristotle." A parallel could be made with the similar pattern of teaching in Padua, where new graduates usually held these lectureships as a temporary position. See Paul F. Grendler, The Universities of the Italian Renaissance (Baltimore: Johns Hopkins University Press 2002), 400.

28. As Francesco Arisi reported at the beginning of the eighteenth century, Giorgio Fondulo had written four books on the subject of medicine: De podagra lib. 3, De modo componendi theriacam, De morbo gallico, and De arborum, \& herbarum natura. Unfortunately, none of them seems to have survived. See Francesco Arisi, Cremona literata, vol. 3 (Cremona: Apud Petrum Ricchini, 1741), 186.

29. He was thus named after Trezzo, a village not far from Milan. In a series of letters (Paris, MS Lat. 7192), Trizio signs his name both in Italian (Paulo di Trezo) and in Latin (Paulus Tricius). Therefore, he is not "Paolo Frizo," as recorded in the inventory of the Bibliothèque Nationale de France and by Antonio Favaro, who follows Benedetti. See Antonio Favaro, "Nuove ricerche sul matematico Leonardo cremonese," Bibliotheca matematica 3 (1905): 329-41. Moreover, in the transcription of the names inscribed in the Rotuli of the University of Pavia a certain Paolo Trizio from Milan is recorded, whom we may identify with Fondulo's friend; in 1510, this Paolo Trizio was teaching Ad lect. medicinae et astrologiae vel philosophiae. He is said to have been writing a book on the construction of astrolabes and the inscription of circles (Corradi, 122). According to Bedini, the Ambrosiana Library of Milan holds a manuscript on the Astrarium attributed to Paolo Tricio; I have browsed through the manuscript which 
trend of education in Renaissance Italy, then we can assume that his encounter with Fondulo took place around the time of this epistolary exchange: that is, between 1505 and 1507.30

This amicable correspondence provides a number of interesting insights into Torriani's later career in mechanics. Both Fondulo and Trizio were educated in medicine (and hence also in astrology) and developed a strong interest in the discipline. Fondulo sent Trizio a list of books he had found in Cremona that included medieval astrological works by Michael Scot, ${ }^{31}$ Abram Avenemre, ${ }^{32}$ and the Ispalense..$^{33}$ Fondulo added that he had also found the book that Trizio had been searching for: the Pratica artis metricae by Leonardo Cremonese, ${ }^{34}$ a kind of manual dealing with geometrical figures and the calculations used by Euclid and Petro de Curte for their measurements, proportions, areas, and volumes. The manuscript also contains a "Cosmography" by the same Leonardo and refers to an obscure instrument "in the shape of a galley, for

\footnotetext{
describes the construction and the use of the astrolabe, but not the Astrarium. It should be noted that two members of the da Trezzo family had previously been involved with medicine and with the Astrarium. Jehan de Trizio was a physician at the time the Astrarium was given to Gian Galeazzo Visconti. A certain Antonio de Trizio was the Milanese ambassador who asked Master Gulielmus (probably Gulielmus Zelandinus), who was employed at the French royal court, to come to Milan to restore the Astrarium for a second time; see Silvio A. Bedini and Francis Maddison, Mechanical Universe: The Astrarium of Giovanni de' Dondi (Philadelphia: American Philosophical Society, 1966), 28.
}

30. According to Campi, Fondulo is said to have taught Torriani astrology even before he had learned to read. If this is true, then we could assume that the tutorship started when Torriani was under the age of seven. In this case, the limits of a hypothetical chronological spread (with five years of age as a reasonable terminus post quem) for the beginning of this process extend from 1505 to 1512. See Zanetti, $78-82$.

31. A well-known medieval translator and courtier to Frederic II of Hohenstaufen, Scot is considered to be one of the most important promoters of Aristotelian texts in Latin Christendom.

32. Perhaps the "In Judiciis" by Abraham Avenemre.

33. Fondulo is probably referring to Johannes Hispalensis, a twelfth-century Jew who converted to Christianity and translated books of astrology and astronomy.

34. Trizio was unable to complete all the demonstrations related to Leonardo's manual, which he had previously copied in Pavia. He wrote that he had been reading the whole of Euclid, but that he could not find out how to complete some demonstrations. Giorgio helped him, thus confuting Trizio's fears that Leonardo might have made some mistakes. Giorgio Fondulo claimed that this Leonardo was the most skilled mathematician of his time. See Bibliothèque Nationale de France, Lat. 7192, "Fondulo, Giorgio, Paolo da Trezzo, et Bernardino Alieri." 
sailing around the world." ${ }^{35}$ In this text we find the instructions for the building of a scientific instrument, accompanied by eighteen illustrations that depict it with two plummets and components that are similar to the parts of an astrolabe and an armillary sphere. ${ }^{36}$ In this letter, Giorgio Fondulo reveals his passion for astronomy and astrology, lamenting that he had little time to pore over astrological books since he had to devote most of his day to the practice of medicine. However, he says that if he were asked then he would be very happy to challenge himself with a mathematical demonstration and with some research by browsing through "dusty old books." In the meanwhile, he asked Trizio to find him some books on alchemy, astrological medicine, and the horoscopes of some famous people. ${ }^{37}$

In his reply to his friend, Trizio reported on a number of experiments that he had carried out by following a version of De spiritalibus by Heron of Alexandria, ${ }^{38}$ the first printed edition of which was still many decades away. Should Fondulo be interested, Trizio promised to send him a description of the machine he had made. Fondulo did not know Heron's work, so he asked for the sketches-now unfortunately missing - that clearly had an explanatory function. ${ }^{39}$ This evidence of the conducting of mechanical experiments by physicians who had been inspired by manuscript copies of Hellenistic treaties is

35. Paris, MS Lat. 7192, Letter 3: “Datum Papie die 18 februarii 1507." This may be one of the many ship-shaped sundials from the period.

36. Paris, MS Lat. 7192, with the title: "Ars instrumenti horologici pro tempore sereno editum per reverendum magistrum Leonardum Cremonensem," which we can translate as "The art of the horological instrument for sunny weather, edited by the reverend master Leonardo of Cremona."

37. Paris, MS Lat. 7192, letter 2: “Datum Cremone die 27 Septembris 1506," and "Ars instrumenti horologici pro tempore sereno editum per reverendum magistrum Leonardum Cremonensem.”

38. Paris, MS Lat. 7192, letter 1: “Datum Papie die 23 Septembri 1506." Letter 2: “Datum Cremone die 27 Septembris 1506." Letter 4: "Cremone die 16 Marcii 1507 a Nativitate."

39. Another very important point to emerge from Fondulo's letter is that both ancient and medieval mechanical knowledge was disseminated through the circulation of manuscripts in the territories around Pavia, Milan, and Cremona: for instance, the Milanese self-declared professor of architecture Cesare Cesariano, the author of the first printed vernacular version of Vitruvius (1521), was acquainted with Heron's and Pappus's manuscripts. In 1567, Giuseppe Ceredi of Piacenza declared that he had previously acquired some manuscripts of Heron and other ancient authors dealing with automata and mechanics from the library of his deceased fellow-countryman and humanist Giorgio Valla ( $\dagger$ 1500), who, in addition to Milan and Venice, had also taught at Pavia. See Maria Luisa Gatti Perer and Alessandro Rovetta, eds., Cesare Cesariano e il classicismo di primo Cinquecento (Milan: Vita e pensiero, 
of great interest. Already in the 1970s, Lynn White Jr. had noted that physicians were the first to produce tracts on engineering and mechanics, and, moreover, that nearly all of those medical astronomers involved with mechanics were court physicians.$^{40}$ After all, among the higher university faculties of theology, law, and medicine, it was the last that was most firmly connected to the study of mathematics-in the form of astronomy/astrology, and the geometrical study of rotary motion - and therefore also to ancient mathematical texts that included treatises on mechanics. ${ }^{41}$

1996), 42; Ceredi, 6; Gianna Gardenal, Patrizia Landucci Ruffo, and Cesare Vasoli, Giorgio Valla tra scienza e sapienza (Florence: Leo S. Olschki, 1981); Zanetti, 80-81.

40. White Jr. argued that this position put them in privileged contact with warfare and stimulated their interest in military machines. See Lynn Townsend White Jr., "Medical Astrologers and Late Medieval Technology," Viator 6 (1975): 295-308.

41. This strong link between Renaissance medicine and mathematics in the form of astronomy/ astrology - based on the geometrical study of rotary motion-seems to provide the best explanation for such interests. Regardless of the availability of printing in the late sixteenth century, it appears that the great mathematical works of ancient Greece had already been recovered and circulated by the end of the fifteenth. These works included Archimedes's corpus, Diophantus's Arithmetica, Pappus of Alexandria's mathematical collection, Heron of Alexandria's mechanical books, Apollonius's Conica, and pseudo-Aristotle's Mechanica (a Greek version had already been published by Aldo Manuzio in 1497). Influential medieval mathematicians were also rediscovered during the same period. Grendler underlines that Leonardo Fibonacci's entire corpus had effectively been ignored throughout the Middle Ages by academics, and it was only thanks to Luca Pacioli that the works of the Pisan were brought to the attention of the public: Grendler, The Universities, 414. On the issue of manuscript copies circulating at Pavia University, see Luciano Gargan, “'Extimatus per bidellum generalem studii Papiensis.' Per una storia del libro universitario a Pavia nel Tre e Quattrocento," in Per Cesare Bozzetti: studi di letteratura e filologia italiana, ed. Simone Albonico (Milan: Fondazione Arnoldo e Alberto Mondadori, 1996), 19-36. For other universities and the problem in a more general context, see Stefano Zamponi, "Exemplaria, manoscritti con indicazione di pecia e liste di tassazione di opere giuridiche," in La production du livre universitaire au Moyen Âge. Exemplar et pecia. Actes du symposium tenu au Collegio San Bonaventura de Grottaferrata en mai 1983, Paris, Éditions du CNRS, 1988, ed. Louis-Jacques Bataillon, Bertrand Georges Guyot, and Richard H. Rouse (Paris; Persee, 1990), 125-32; Stefano Zamponi, "Manoscritti con indicazioni di pecia nell'Archivio Capitolare di Pistoia," in Università e società nei secoli XII-XVI. Nono convegno internazionale (Pistoia, 20-25 settembre 1979) (Pistoia: Centro italiano di studi di storia e d'arte, 1982), 447-84; Jean Destrez, La Pecia dans les manuscrits universitaires du XIIIe et du XIVe siècle (Paris: Éd. Vautrain, 1935); Giulio Battelli, "Il libro universitario," in Civiltà comunale: libro, scrittura, documento: atti del Convegno, Genova, 8-11 novembre 1988, vol. 2., Atti della Società ligure di storia patria 29 (Genoa: Società ligure di storia patria / Associazione italiana dei paleografi e diplomatisti / Istituto di civiltà classica cristiana medievale, Università di Genova, 1989), 281-313; Gargan, "Le note 
Giorgio Fondulo offered another significant clue to this cultural milieu when he lamented that he was a busy physician with little time to dedicate to his passion, the study of mathematics - particularly its astrological side. Indeed, in his letters he confirmed his great pleasure in discussing, demonstrating, and searching for mathematical issues. This "love of knowledge," as Trizio calls it, ${ }^{42}$ was expressed not only through epistolary inquires or by the exchange of books. Fondulo was also committed to supporting students who were young and poor-a factor that became crucial in the shaping of Torriani's knowledge. The civic commitment to the education of such Renaissance men emerges in this correspondence, as Trizio recommends to his friend in Cremona a thirteenyear-old boy, the son of a deceased professor at the University of Pavia. The boy, Aurelio Grasso, was set to study Latin grammar in Cremona. ${ }^{43}$ Fondulo responds that he intended to offer Aurelio intellectual and material support. Fondulo's dedication to the young protégé remains a constant throughout all his letters. ${ }^{44}$ Even his will bears witness to his social commitment to education: the physician left enough resources to maintain not only four physicians and surgeons to take care of the indigent, but also to support an academy dedicated

"conduxit». Libri di maestri e studenti nelle Università italiane del Tre e Quattrocento," in Manuels, programmes de cours et techniques d' enseignement dans les universités médiévales: actes du Colloque international de Louvain-la-Neuve, 9-11 septembre 1993, ed. Jacqueline Hamesse (Louvain-la-Neuve: Institut d’Études Médiévales, 1994), 385-400.

42. "lamor de la scientia”; see Paris, MS Lat. 7192, letter 3: "Datum papie die 18 february 1507."

43. "Post scripta venie li uno putto chiamato Aurelio figliolo del quondam Magistro M(agnifico?) Petro Grasso legente in studio qui rason Canonica il qual starà li in dozena per imparare le Gramaticale littere. Prego vogliati cercarlo et offerirli quello posseti per lui per amor mio, et velo racomando accadendo: è di età circha 13 anni bono filiolo et accostumato"; Paris, MS Lat. 7192, letter 1: "Datum Papie die 23 Septembri 1506." Pietro Grassi's family was of Milanese nobility, and a homonymous uncle of his had been bishop of Pavia ( $\dagger$ 1426). Grassi taught at the University of Pavia until his death in 1505. See Corradi, 59; Gigliola di Renzo Villata, s.v. “Grassi, Pietro," Dizionario biografico degli Italiani, vol. 58 (Rome: Istituto della Enciclopedia italiana, 2002), online, http://www.treccani.it/enciclopedia/ pietro-grassi_\%28Dizionario_Biografico\%29/.

44. Paris, MS Lat. 7192, letter 2: “Datum Cremone die 27 Septembris 1506." It is interesting to observe here the practice of early sixteenth-century education, scattered among different cities. From Aurelio Grasso's story we learn of a geographical distribution of schools that provided different levels of education. A university town like Pavia was probably not considered as suitable for pre-academic education as Cremona was. Unfortunately, it is not possible to be sure of all the possible reasons that Grasso went to Cremona, and this decision could indeed have been influenced by some family strategy unknown to us. 
to any subject relating to Latin or vernacular letters. If the academy was not to be established, then a bequest had to be made in order to support eight poor youths in their studies, providing them with the money to purchase books and pay teachers. Giorgio's brother, Cristoforo Fondulo, was said to have emulated his sibling in such testamentary generosity. ${ }^{45}$

In the aforementioned epistolary exchange, among the friends that Fondulo asks Trizio to greet on his behalf in Pavia, all of whom were involved with medicine, ${ }^{46}$ was Ambrogio Rosate ${ }^{47}$ known as Varesio. From 1494, Varesio had been astrologer and physician to Duke Ludovico il Moro, who granted him the fief of Rosate, between Milan and Pavia. By 1495, the duke had had the Astrarium transported to the castello in Rosate, where it remained for a year. It is difficult to imagine that with this array of friends involved in mathematical and astrological studies, especially Rosate, Fondulo did not have access to the Astrarium. ${ }^{48}$

45. Francesco Robolotti, “Dei medici cremonesi," Effemeridi delle scienze mediche 9 (1839): 290-322, 312 .

46. Rosati, Bobio, Rustico, Balbo, de Laquila: from the rotuli of Pavia University it seems they were all involved with the teaching of medicine, and therefore also with astrology. Some also appear to have been employed at the ducal court. "Che me ricomandati alli nostri amici vechi: principalmente accadendo ali nostri Rosati: al Bobio: al Rustico: al Balbo: de Laquila." Bobio can be identified with Francesco Bobbio appointed "ad lect. Logicae ordin. De mane et Sophistariae" in 1480, and "ad Medicinae ordin. de mane" in 1483, and 1511. The rotuli mention another professor named Bobbio, but I do not think this other individual with the same name could fit into this consistent group of physicians: Uberto Bobbio was professor of law between 1510 and 1525. Rustico may be identified with Pietro Antonio Rustico, perhaps from Piacenza, who was appointed in 1486 to lecture "philosophia", and in 1487 "ad lect. Medicinae ord." Balbi should instead be identified with Agostino Balbi of Pavia who in 1483 and 1499 was in charge of lecturing "Praticae Medicinae extraord. de nonis"; he died in 1512. Finally, de Laquila must be the Sebastiano Aquila, perhaps of Pavia, who in 1500 was appointed "ad lect. Medicinae." See Corradi, Memorie e documenti.

47. Corradi, Memorie e documenti. At the University of Pavia he was appointed "ad lecturam Fisicae naturalis" in the year 1461, and in 1486 and 1500 "ad lecturam Almansoris." There was also a second Rosate who could be less easily identified with the one mentioned in the letter: this was Giovanni, known as Monferrato, from Rosate, who in 1467 was appointed "ad lect. Chirurgiae," after which he was made administrator of the hospital of S. Matteo, and physician to the count of Pitigliano (condottiere of the army of the Duke of Milan). Latterly from 1500 onwards, because of his political connections with the Sforza, he was exonerated from teaching, eventually dying in 1515.

48. On the circulation of astrological books between the University of Pavia and the Sforza court in the fifteenth century, see Monica Azzolini, The Duke and the Stars: Astrology and Politics in Renaissance 
It seems that Torriani's story replicates a process that we have observed also in the "making" of other Renaissance artisanal polymaths, above all Brunelleschi. According to this educational model, Renaissance universitytrained mathematicians, who were usually physicians, played a particularly important role in turning simple craftsmen into superior ones, translating and transmitting Latin and Greek knowledge into the vernacular, and dressing up the most skilled and receptive members of the crafts with the ancient and noble masks of Archimedes, Vitruvius, Daedalus, etc. Pappus, in the volume (8) of his Mathematical Collections devoted to mechanics, well describes the model for the Renaissance polymath quadrivialis, whom he calls "chief-artificer," and whom we may define as the "Vitruvian artisan":

Some of Heron's followers who have studied the science of mechanics have stated that this is in part theoretical and in part practical, the former being derived from geometry, arithmetic, astronomy, and the natural sciences, while the latter is brought to perfection through the techniques of blacksmiths and coppersmiths, builders, carpenters and sculptors, and their skill and subtlety in their work. A man who had studied the sciences which we have just listed since his youth and had become expert in knowledge of the crafts which we have mentioned [...] would, according to these people, excel in finding out mechanical contrivances, and he it was whom they used to call "chief-artificer." ${ }^{49}$

The absence of specific curricula for engineers, clockmakers, architects, and other artisans involved with disegno turned these superior craftsmen into de facto polymaths, unifying their knowledge of a practical discipline with their learning of a theoretical system that belonged to the curricula of other professions. All these "many disciplines" that were part of the superior craftsman's polymathesis belonged to the neo-Hellenistic Renaissance concept of mathematics, consisting both of the medieval quadrivium and the Aristotelian mixed mathematics of the Renaissance. During the sixteenth century, these new-old

Milan (Cambridge, MA: Harvard University Press, 2013), ch. 1; 51n119, for information regarding university professors borrowing books from the ducal library.

49. Pappus Alexandrinus, The Arabic Version of the Mathematical Collection of Pappus Alexandrinus, book 8, a critical edition, ed. D. E. P. Jackson (PhD thesis, Cambridge, 1970), 2. 
careers will become institutionalized through new curricula, turning the experiences of these polymaths into organized mathematical professions. 